\title{
Pelatihan Peningkatan Kemampuan Komunikasi Bisnis Kelompok Usaha Bersama Ibu-Ibu PKK Desa Tempeh Lor Kecamatan Tempeh
}

\author{
Mimin Yatminiwati \\ STIE Widya Gama Lumajang \\ Email : miminyatminiwati02@gmail.com
}

\begin{abstract}
ABSTRAK
Komunikasi yang baik dan benar sangatlah penting dilakukan oleh seorang wirausahawan. Komunikasi adalah kegiatan penyampaian, penerimaan dan pengolahan pesan dari seseorang kepada orang lain. Komunikasi erat kaitannya dengan sistem indra. Contoh: pendengaran. Kemampuan berkomunikasi dapat disebut sebagai kemampuan berbahasa karena dalam berkomunikasi digunakan bahasa sebagai media utamanya. Oleh karena itu penulis merasa perlu memberikan pelatihan Peningkatan Kemampuan Komunikasi Bisnis Kelompok Usaha Bersama Ibu-Ibu PKK Desa Tempeh Lor Kecamatan Tempeh Tahun 2017.
\end{abstract}

\section{Kata Kunci : Komunikasi Bisnis, Kelompok Usaha Bersama, Tempeh Lor}

ABSTRACT
Good and proper communication is very important to be done by an entrepreneur. Communication is the activity of delivering, receiving and processing messages from one person to another. Communication is closely related to the sensory system. Example: hearing. The ability to communicate can be called as the ability to speak because the language is used as a language communications. Therefore, the authors feel the need to provide training Improvement of Business Communication Skills Business Group with Mother PKK Tempeh Lor Village District Tempeh Year 2017.

\section{Keywords: Business Communication, Business Group Together, Tempeh Lor}

\section{PENDAHULUAN}

\section{A. Analisis Situasi}

Komunikasi adalah kegiatan penyampaian, penerimaan dan pengolahan pesan dari seseorang kepada orang lain. Komunikasi erat kaitannya dengan sistem indra. Contoh: pendengaran. Kemampuan berkomunikasi dapat disebut sebagai kemampuan berbahasa karena dalam berkomunikasi digunakan bahasa sebagai media utamanya. Kemampuan berkomunikasi dapat dibedakan menjadi: (1). kemampuan menyimak (listening competence) (2). kemampuan berbicara (speaking competence), (3). kemampuan membaca ( reading competence) (4). kemampuan menulis (writing competence). Bentuk dasar komunikasi ada 2 yaitu (1). Komunikasi nonverbal adalah kumpulan isyarat, gerak tubuh, intonasi suara, sikap yang memungkinkan seseorang untuk berkomunikasi tanpa kata-kata (Bovee dan Thill, 2003:4). Komunikasi nonverbal disebut bahasa isyarat atau bahasa diam (silent language). Fungsi komunikasi nonverbal adalah: (1) Meyakinkan apa yang diucapkan (repetition) (2) Menunjukkan perasaan atau emosi yang tidak bisa diutarakan dengan kata-kata (3) Menunjukkan jati diri sehingga orang lain bisa mengenalnya (identity) (4) Menambah atau melengkapi ucapan-ucapan yang dirasa belum sempurna. 
Komunikasi verbal merupakan bentuk komunikasi di mana pesan disampaikan secara lisan atau tertulis menggunakan bahasa. Bentuk komunikasi verbal yaitu lisan atau oral comunication (berbicara dan mendengar), tulis atau writen comunication ( menulis dan membaca). Komunikasi yang tidak diorganisasikan dengan baik bermasalah dalam isi, pengelompokan, dan urutan butirbutir pesan dan juga akan sulit dipahami serta dapat berakibat adanya rasa frustasi pada penerima. Hal-hal berikut bisa menyebabkan tidak baiknya pesan bisnis yaitu (1). Bagian awal terlalu panjang (bertele-tele) (2). Memasukkan hal-hal yang tidak relevan dan tidak logis (3). Informasi penting terlupakan (4) Pengelompokan dan urutan pesan tidak menunjukkan satu kesatuan yang logis. Mengorganisasikan pesan dengan baik dapat dilakukan melalui tiga langkah berikut: (1) Menetapkan ide/ gagasan pokok (2)Mengelompokkan ide/gagasan (3) Memutuskan pola atau pendekatan urutan gagasan. Pola atau pendekatan yang dapat digunakan, yaitu: 1. Pendekatan deduktif atau langsung (direct approach) (2) Pendekatan induktif atau tidak langsung(indirect approach)

Komunikasi yang efektif memegang peranan penting dalam bisnis. Komunikasi bisnis tertulis dikatakan efektif apabila memenuhi karakteristik sbb:(1) Courtesy (sopan santun), (2) Correctness (tepat/benar), (3) Conciseness (ringkas)(4) Clarity atau Clearness (jelas), (5) Cocreteness (tepat), (6) Completeness (lengkap).

Komunikasi yang baik dan benar sangatlah penting dilakukan oleh seorang wirausahawan. Oleh karena itu penulis merasa perlu memberikan pelatihan Peningkatan Kemampuan Komunikasi Bisnis Kelompok Usaha Bersama Ibu-Ibu PKK Desa Tempeh Lor Kecamatan Tempeh Tahun 2017

\section{B. Permasalahan Mitra}

Kurangnya Kemampuan Komunikasi Bisnis Kelompok Usaha Bersama Ibu-Ibu PKK Desa Tempeh Lor Kecamatan Tempeh.

\section{Solusi yang Ditawarkan}

Mengembangkan usaha bersama kelompok ibu-ibu PKK desa Tempeh Lor melalui media sosial

\section{Target Luaran}

Luaran dalam kegiatan masyarakat ini yaitu, mampu komunikasi dalam memasarkan produk melalui media sosial

\section{METODE PELAKSANAAN}

Metode pelaksanaan kegiatan dilakukan melalui tahapan sebagai berikut:

Kegiatan ini dilaksanakan 2 hari yang pertama di Balai Desa Tempeh Lor Jalan Raya Tempeh Kecamatan Tempeh dan yang kedua di rumah warga dusun Tulus Rejo II desa Tempeh Lor. Bentuk Kegiatan Pelatihan Peningkatan Kemampuan Komunikasi Bisnis dan Wirausaha Kelompok Usaha Bersama Ibu-Ibu PKK desa Tempeh Lor kecamatan Tempeh adalah: 
a. Penyampaian Materi

b. Umpan Balik

c. Diskusi

\section{Materi Kegiatan}

Materi dalam pelatihan ini adalah : "Menumbuhkan Komunikasi Bisnis bagi Kelompok Usaha Bersama Ibu-Ibu PKK Desa Tempeh Lor Kecamatan Tempeh”, dengan kisi-kisi sebagai berikut:

a. Definisi Komunikasi Bisnis

b. Unsur-unsur Komunikasi

c. Bentuk Dasar Komunikasi

d. Sikap dalam Komunikasi

e. Teknik Komunikasi Secara Efektif

\section{HASIL YANG DICAPAI}

Kelompok usaha mampu berkomunikasi baik secara verbal maupun non verbal. Fungsi komunikasi nonverbal adalah: (1) Meyakinkan apa yang diucapkan (repetition) (2) Menunjukkan perasaan atau emosi yang tidak bisa diutarakan dengan kata-kata (3) Menunjukkan jati diri sehingga orang lain bisa mengenalnya (identity) (4) Menambah atau melengkapi ucapan-ucapan yang dirasa belum sempurna.

Komunikasi verbal merupakan bentuk komunikasi di mana pesan disampaikan secara lisan atau tertulis menggunakan bahasa. Bentuk komunikasi verbal yaitu lisan atau oral comunication (berbicara dan mendengar), tulis atau writen comunication ( menulis dan membaca). Komunikasi yang tidak diorganisasikan dengan baik bermasalah dalam isi, pengelompokan, dan urutan butirbutir pesan dan juga akan sulit dipahami serta dapat berakibat adanya rasa frustasi pada penerima. Hal-hal berikut bisa menyebabkan tidak baiknya pesan bisnis yaitu (1). Bagian awal terlalu panjang (bertele-tele) (2). Memasukkan hal-hal yang tidak relevan dan tidak logis (3). Informasi penting terlupakan (4) Pengelompokan dan urutan pesan tidak menunjukkan satu kesatuan yang logis. Mengorganisasikan pesan dengan baik dapat dilakukan melalui tiga langkah berikut: (1) Menetapkan ide/ gagasan pokok (2)Mengelompokkan ide/gagasan (3) Memutuskan pola atau pendekatan urutan gagasan. Pola atau pendekatan yang dapat digunakan, yaitu: 1. Pendekatan deduktif atau langsung (direct approach) (2) Pendekatan induktif atau tidak langsung (indirect approach). 
Selain itu, kelompok usaha juga mampu berkomunikasi yang efektif dalam bisnis.

Komunikasi bisnis tertulis dikatakan efektif apabila memenuhi karakteristik :(1) Courtesy (sopan santun), (2) Correctness (tepat/benar), (3) Conciseness (ringkas)(4) Clarity atau Clearness (jelas), (5) Cocreteness (tepat), dan (6) Completeness (lengkap).
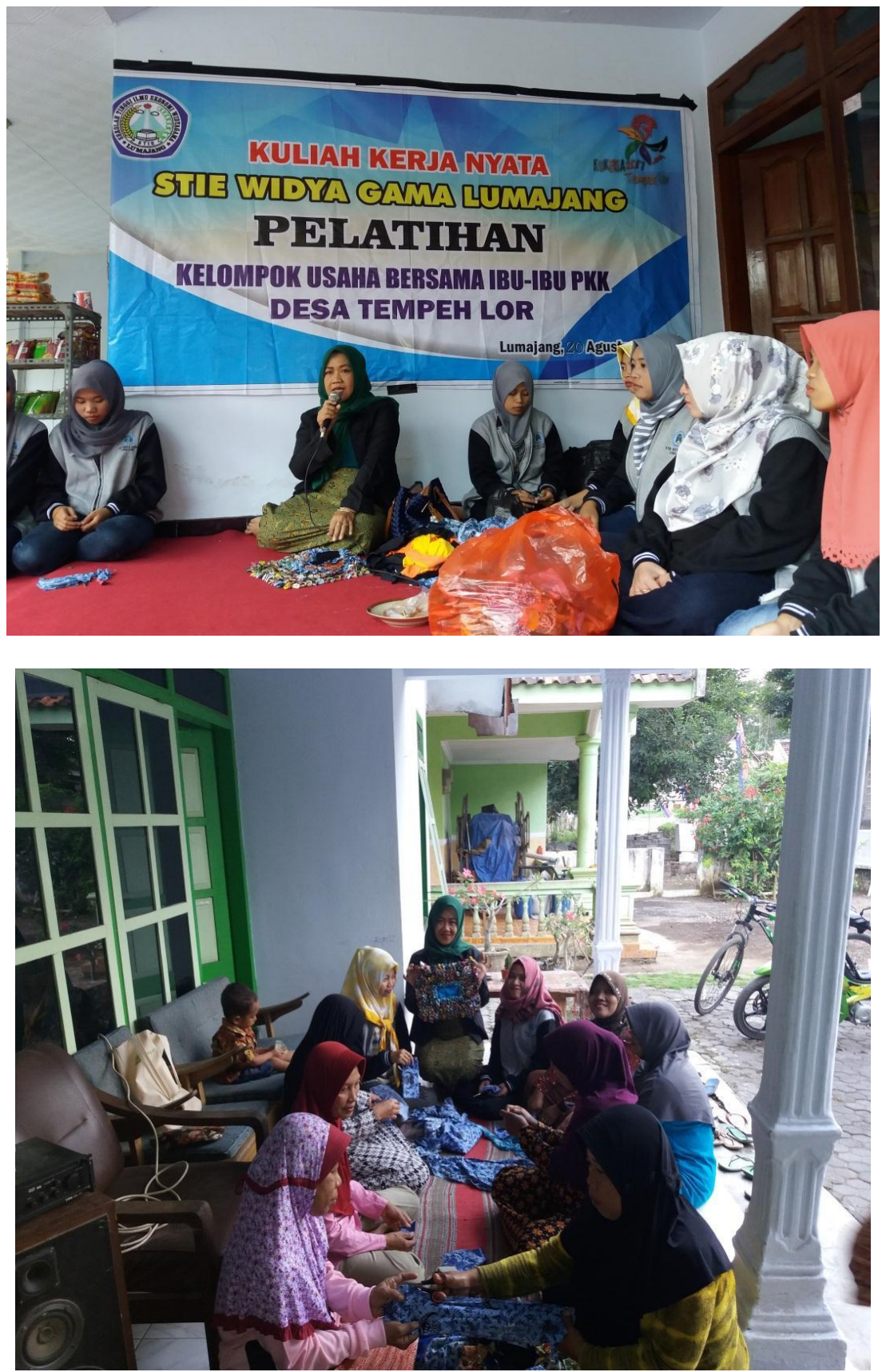

\section{Simpulan}

Pelatihan peningkatan komunikasi bisnis dengan kelompok usaha antaralain meliputi kegiatan berkomunikasi yang efektif dalam bisnis, komunikasi non verbal, dan komunikasi verbal. Komunikasi verbal merupakan bentuk komunikasi di mana pesan disampaikan secara lisan atau tertulis menggunakan bahasa. Bentuk komunikasi verbal yaitu lisan atau oral comunication (berbicara dan mendengar), tulis atau writen comunication ( menulis dan membaca). Komunikasi yang tidak 
diorganisasikan dengan baik bermasalah dalam isi, pengelompokan, dan urutan butir-butir pesan dan juga akan sulit dipahami serta dapat berakibat adanya rasa frustasi pada penerima.

\section{Saran}

Kelompok usaha Ibu-Ibu PKK Desa Tempeh Lor Kecamatan Tempeh diharapkan dapat mengorganisasikan pesan dengan baik melalui tiga langkah berikut:

(1) Menetapkan ide/ gagasan pokok

(2) Mengelompokkan ide/gagasan

(3) Memutuskan pola atau pendekatan urutan gagasan

\section{DAFTAR PUSTAKA}

Saiman, Leonardus. 2014. Kewirausahaan Teori, Praktik, dan Kasus-kasus.

Jakarta: Salemba Empat. 